\title{
Distribution and Seasonal Variation of Nutrient Salts and Chlorophyll-a in Surface Seawater Along Alexandria Costal Zone Area
}

\author{
Edweb Ali Salem Dango ${ }^{1}$, Mahmoud Salem Ibrahim², Mohamed Abel Aziz Okbah ${ }^{3}$, \\ Mei Ibrahim El Gmaal ${ }^{2}$ \\ ${ }^{1}$ High Institute in Jerpoly area, Tripoli, Libya \\ ${ }^{2}$ Environmental Science Department, Faculty of Science, Damietta University, Damietta, Egypt \\ ${ }^{3}$ National Institute of Oceanography \& Fisheries, Kayet Bay, Alexandria, Egypt \\ Email address: \\ dwiebi_dango@yahoo.com (E. A. S. Dango), mahmoud salem1912@gmail.com (M. S. Ibrahim), m_okbah@yahoo.com (M. A. Okbah), \\ mgammal147@du.edu.eg (M. I. E. Gmaal)
}

\section{To cite this article:}

Edweb Ali Salem Dango, Mahmoud Salem Ibrahim, Mohamed Abel Aziz Okbah, Mei Ibrahim El Gmaal. Distribution and Seasonal Variation of Nutrient Salts and Chlorophyll-a in Surface Seawater Along Alexandria Costal Zone Area. Science Research.

Vol. 3, No. 4, 2015, pp. 180-190. doi: 10.11648/j.sr.20150304.15

\begin{abstract}
The aim of the present study is to investigate the hydrographic characteristics, nutrient salts and chlorophyll-a (Chl-a) along Alexandria Costal Zone Area. The study revealed that the $\mathrm{pH}$ values lie slightly in the alkaline side, with a range of 7.53 to 8.12, salinity showed a slightly variation, it ranged from 35.34 to 38.28 PSU, the values of dissolved oxygen were fluctuated between 4.77 and $11.13 \mathrm{mgl}^{-1}$. The annual average of nutrients $(\mu \mathrm{M})$ was as follow: $(7.97 \pm 1.72),(0.66 \pm 0.14),(2.18 \pm 0.73)$, $(0.37 \pm 0.09)$ and $(12.42 \pm 4.04)$ for nitrate, nitrite, ammonium, reactive phosphate and silicate, respectively. Relatively high levels of Chl-a concentrations was recorded during the period of study ranged from 0.38 to $6.96 \mu \mathrm{gl}^{-1}$ and a positive correlation was found between Chl-a and both $\mathrm{NO}_{3}, \mathrm{NH}_{4}, \mathrm{PO}_{4}$ and $\mathrm{SiO}_{4}(\mathrm{r}=0.383,0.303,0.213$ and 0.341 , respectively). Very high values of $\mathrm{N} / \mathrm{P}$ ratio were recorded during the study period, this consideration showed that Phosphorus was limiting factor in the study area.
\end{abstract}

Keywords: N/P Ratio, Nutrients, Chlorophyll-a, Alexandria

\section{Introduction}

Alexandria is an Egypt's largest city on the Mediterranean coast, and is one of the most important industrial centers, comprised 100 large factories and about 260 smaller ones [1], to cover about $40 \%$ of the nation's industry. It is also the main summer resort in Egypt; about 4 million citizen and two million summer visitors [2]. The Alexandria coastal zone is about 42 $\mathrm{km}$ long, extending from El-Dekhaila in the west to Abu Qir in the east, and consists of pockets and embayment beaches morphology. In addition to its moderate temperature in summer and winter, its beaches, with soft sands and magnificent scenery, are considered very important natural resources. The coastal zone of Alexandria is presently experiencing a number of problems resulting from a considerable amount of wastewater is discharged into the coastal zone of Alexandria from the surrounding area $[3,4,5]$. This occurs extensively at six regions, Mamoura region, Edku lake inlet, El Tabia pumping station,
Eastern Harbor, western harbor and El Mex pumping station. Abu Qir Bay is considered a fertile marine habitat, comparing to other Egyptian Mediterranean coastal waters. The bay is suffered from many pollution sources, which discharged through El-Tabia outfall, Maadia outlet and the Rosetta branch of the River Nile. El-Mex district is an industrial zone, west of Alexandria City. As a consequence of growing heavy industries (petrochemicals, pulp metal planting, industrial dyes, and textiles) and the uncontrolled disposal of the resulting waste, the costal water of El-Mex Bay receives huge amounts of untreated industrial wastes $[6,7]$. These wastes are containing potentially toxic materials, which are pumped directly into the bay via a pipeline in its southern part. El-Mex Bay receives a heavy load of wastewater $(2.4 \times 109 \mathrm{~m} 3 /$ year $)$ both directly to the sea from industrial outfalls and indirectly from Lake Maryout via El-Mex Pumping station [8], which lies about $1 \mathrm{~km}$ upstream on 
El-Umum Drain, is mainly agricultural drainage water collected by El-Umum Drain but also comprises the overflow from Lake Maryout [9]. Also, shipping activities in the harbors (eastern and western harbors as well as the Bays; El-Mex and Abu Qir Bays) contribute to the area pollution [10]. The study of pollutants in the Egyptian Mediterranean Sea has been investigated by numerous workers $[11,12]$. (Shreadah et al. 2012; Abdel Ghani et al. 2013).

The aim of the present study was to investigate the water quality of Alexandria costal area by measuring seasonal variation of physical and chemical characteristics of the costal area water. It will be a useful tool to authorities in charge of sustainable marine management.

\section{Material and Methods}

\subsection{Study Areas}

Ten surface water samples were collected seasonally from the coastal zone of Alexandria using plastic Rottener Sampler of 2 liters capacity. Trips for sampled collection were carried out on a boat. Sampling periods were performed in June, September, December 2013, March and June 2014.Sampling stations were chosen covering the different locations of the costal area (Figure 1).

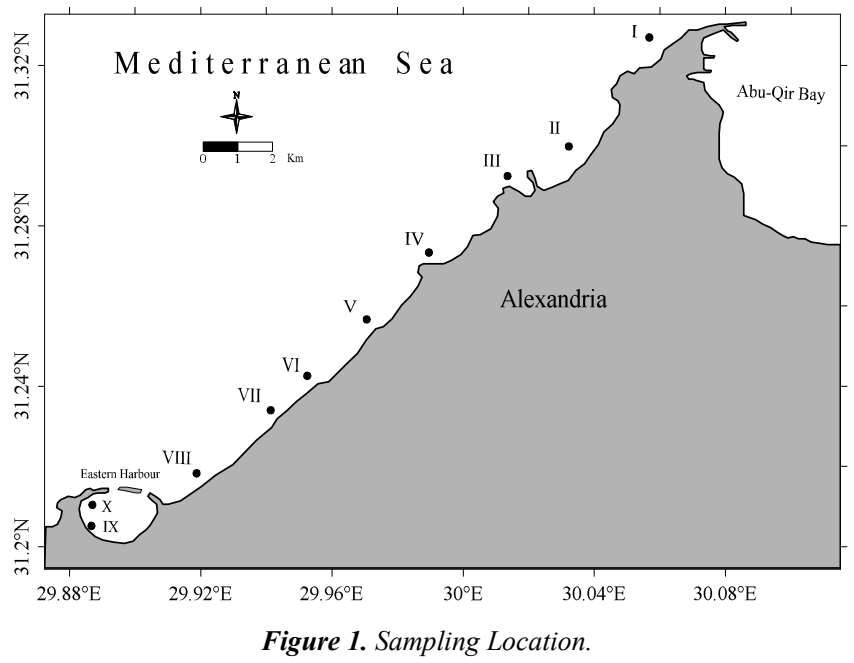

\subsection{Analysis of Seawater}

The water temperature was measured with an ordinary thermometer. The $\mathrm{pH}$ value was measured using a pocket $\mathrm{pH}$ meter (model 201/digital pH meter). Water transparency was carried out by a white secchi depth $25 \mathrm{~cm}$ in diameter. Water salinity was measured using Bechman salinometer (Model NO. R.S.10). Dissolved oxygen was estimated according to the Winkler method. Samples for nutrient salts were immediately filtered through Whatman GF/C filters and kept frozen until analysis. Samples of ammonium were fixed in the field without filtration. Chemical oxygen demand (COD) was determined using permanganate values test [13]. Dissolved inorganic nitrogen compounds $\mathrm{DIN}\left(\mathrm{NH}_{4}-\mathrm{N}, \mathrm{NO}_{2}-\mathrm{N}\right.$ and $\left.\mathrm{NO}_{3}-\mathrm{N}\right)$, reactive phosphate $\left(\mathrm{PO}_{4}-\mathrm{P}\right)$ and reactive silicate
$\left(\mathrm{SiO}_{4}\right)$ were determined according to Grasshoff (1976) [14]. Chlorophyll- $a$ in the surface water was extracted with $90 \%$ acetone and measured spectrophotometrically using the SCORE UNESCO equation given in [15].The measurements of dissolved nutrient salts $\left(\mathrm{PO}_{4}-\mathrm{P}, \mathrm{NH}_{4}-\mathrm{N}, \mathrm{NO}_{2}-\mathrm{N}, \mathrm{NO}_{3}-\mathrm{N}\right.$ and $\mathrm{SiO}_{4}$ ) and Chlorophyll- $a$ were performed using a Shimadzu double beam spectrophotometer UV-150-02. Total Suspended matter (TSM) was determined from $2 \mathrm{~L}$ of water sample, filtered through the filter paper $(\mathrm{GF} / \mathrm{C}, 0.45 \mu \mathrm{m})$, the TSM value was calculated by the difference between the dry weight of the filter before and after filtration. Eutrophication Index was calculated according to Tomotoshi (1972) [16] as the following: $\left[\left(\mathrm{COD} \times \mathrm{NO}_{3} \times \mathrm{PO}_{4}\right) / 4500\right] \times 10^{6} \geq 1$. Matrix correlation, Nitrogen / Phosphorus ratio (N/P ratio) and simple regression equations at $p=0.05$ were estimated to reveal the relationship between the $\mathrm{Chl}-\mathrm{a}$ and nutrient salts concentrations. These analyses were applied to interpret the data and to get better information about the water types of the studied system.

\section{Results Discussion}

\subsection{Hydrographic Conditions}

Water temperature, the $\mathrm{pH}$ values of the investigated area, Water salinity and dissolved oxygen (DO) were studied, the hydrographic conditions varied widely during the study period

\subsection{Water Temperature}

Seasonal values of water temperature over the coastal area varied in the range of $18.20{ }^{\circ} \mathrm{C}$ and $27.5{ }^{\circ} \mathrm{C}$ (Table1). The lowest temperature was recorded in December 2013 and increased to reach the highest level in September 2013 (Figure2).

\subsection{Water Transparency}

Seawater transparency (Secchi depth) of the study area from Abu Qir Bay (St.I) to the eastern Harbour (St.X) was recorded in Table1. It was relatively high for almost the whole year, with Secchi disc readings varying from 2.00 to $4.00 \mathrm{~m}$ (Figure2). The water was more relatively clear during the period of study. This may be attributed to the low content of chlorophyll-a, since the annual mean ranged from $1.92 \pm 0.84$ to $3.30 \pm 2.78 .4 \mu \mathrm{gl}^{-1}$ related to the phytoplankton density.

\subsection{Hydrogen Ion Concentration (pH)}

The values of $\mathrm{pH}$ of the investigated area lie on the alkaline side, its values ranging between 7.53 (station V in March 2014) and 8.19 (station VIII in December 2013). The results of $\mathrm{pH}$ values at most of stations decrease than that normal $\mathrm{pH}$ value of seawater (8.20) observed during June, September 2013 and March 2014 due to wastewater inputs (Table 1 and Figure2).

\subsection{Water Salinity (PSU)}

The salinity is an important factor which reflects the changes caused by the mixing of fresh water, drainage water 
and seawater. The variation of water salinity was recorded in Table1 and Figure2. The lowest value (35.34 PSU) was recorded at station IX during December 2013, while the highest one (38.28 PSU) was recorded at station VII during September 2013. The low mean value of salinity recorded in December 2013 and June 2014 (36.01 \pm 0.41 PSU), it was decreased than that reported in the other season. The present data of water salinity showed slightly variations. The results are similar to those reported by Fahmy, et al. (1997) [7]. There is a significant positive relationship between water salinity and temperature

$$
\text { Salinity }=33.62+0.148 \mathrm{~T}^{\circ} \mathrm{C} \mathrm{r}=0.450 \text { at } P<0.05 \mathrm{n}=50
$$

\subsection{Dissolved oxygen (DO)}

Dissolved oxygen (D.O) in natural waters is introduced by either diffusion from, or turbulent mixing with, air; or by the photosynthesis of aquatic plants. It varies inversely with (1) temperature, (2) the dissolved solids content of the water, and (3) with altitude. Fish and macro invertebrates do not obtain their oxygen from the air, but rather the dissolved oxygen molecules in the water. DO is affected by the temperature, becoming larger when the water temperature is cooler, and vice versa. The results of DO value varied between 4.77 and $11.13 \mathrm{mg} / \mathrm{l}$ in the study area (Table1 and Figure3), which the lower value was recorded at station X in June 2014 while the highest value was recorded at station I in December 2013. Generally, the increasing of water temperature leads to the decreasing of DO. This confirmed with a significant negative correlation $(r=-0.40)$. This may be due to several factors, the rise in temperature increased biological activity, respiration of organisms and increased rate of decomposition of organic matter.

$\mathrm{DO}=-0.377+1.52 * \mathrm{pH}+0.79 *$ Salinity $-0.09 * \mathrm{~T}^{0 \mathrm{C}}+0.29 * \mathrm{BOD}+0.14 * \mathrm{COD}-0.002 * \mathrm{SPM} \mathrm{r}=0.512$, at $\mathrm{P}<0.05 \mathrm{n}=50^{\circ} \mathrm{C}$

Table 1. Range and Average \pm S. D. of some parameters in Alexandria coastal zone water during 2013-2014.

\begin{tabular}{|c|c|c|c|c|c|c|}
\hline \multirow{3}{*}{ Parameter } & Summer & Autumn & Winter & Spring & Summer & \multirow{3}{*}{ Annual Average } \\
\hline & June & September & December & March & June & \\
\hline & \multicolumn{2}{|l|}{2013} & & \multicolumn{2}{|l|}{2014} & \\
\hline $\mathrm{pH}$ & $7.76-8.12$ & $7.75-7.98$ & $7.84-8.19$ & $7.53-7.85$ & $7.66-8.12$ & \\
\hline \multirow{2}{*}{ Salinity(PSU) } & $37.68-38.22$ & $37.44-38.28$ & $35.34-36.66$ & $36.00-38.00$ & $35.34-36.66$ & $37.44-36.26$ \\
\hline & $37.91 \pm 0.52$ & $37.94 \pm 0.31$ & $36.01 \pm 0.43$ & $37.50 \pm 0.53$ & $36.01 \pm 0.43$ & $37.94 \pm 0.31$ \\
\hline \multirow{2}{*}{ Temper. $\left({ }^{\circ} \mathrm{C}\right)$} & $25.20-27.10$ & $26.20-27.50$ & $18.20-20.01$ & $19.80-20.60$ & $23.80-24.30$ & $23.24-23.80$ \\
\hline & $26.01 \pm 0.65$ & $26.98 \pm 0.45$ & $19.81 \pm 0.57$ & $20.16 \pm 0.35$ & $24.08 \pm 0.19$ & $23.41 \pm 0.17$ \\
\hline \multirow{2}{*}{$\mathrm{DO}, \mathrm{mgL}^{-1}$} & $6.35-8.90$ & $6.35-7.94$ & $6.35-11.13$ & $5.10-9.63$ & $4.77-8.90$ & $6.17-8.66$ \\
\hline & $7.40 \pm 0.81$ & $7.24 \pm 0.76$ & $8.55 \pm 1.54$ & $8.14 \pm 1.40$ & $6.71 \pm 1.37$ & $7.61 \pm 0.75$ \\
\hline \multirow{2}{*}{$\mathrm{BOD}, \mathrm{mgL}^{-1}$} & $0.95-4.44$ & $0.31-5.09$ & $0.96-6.40$ & $3.08-4.67$ & $0.95-5.72$ & $1.82-4.26$ \\
\hline & $2.54 \pm 1.31$ & $2.82 \pm 1.45$ & $3.65 \pm 1.85$ & $3.89 \pm 0.66$ & $2.54 \pm 1.59$ & $3.09 \pm 0.84$ \\
\hline \multirow{2}{*}{$\mathrm{COD}, \mathrm{mgL}^{-1}$} & $3.20-11.20$ & $3.52-9.60$ & $2.86-8.26$ & $5.66-8.22$ & $6.52-12.50$ & $4.80-8.86$ \\
\hline & $6.50 \pm 2.36$ & $6.59 \pm 2.32$ & $6.11 \pm 2.06$ & $6.66 \pm 0.72$ & $8.95 \pm 1.94$ & $6.96 \pm 1.20$ \\
\hline \multirow{2}{*}{$\mathrm{NO}_{2} / \mathrm{N}(\mu \mathrm{M})$} & $0.07-0.90$ & $0.10-0.96$ & $0.93-1.82$ & $0.01-0.47$ & $0.36-1.22$ & $0.44-0.87$ \\
\hline & $0.26 \pm 0.26$ & $0.50 \pm 0.27$ & $1.36 \pm 0.24$ & $0.25 \pm 0.15$ & $0.76 \pm 0.25$ & $0.66 \pm 0.14$ \\
\hline \multirow{2}{*}{$\mathrm{NH}_{4} / \mathrm{N}(\mu \mathrm{M})$} & $1.51-8.97$ & $1.16-7.55$ & $0.10-0.45$ & $0.27-0.80$ & $0.57-1.34$ & $1.52-3.41$ \\
\hline & $5.16 \pm 2.36$ & $3.98 \pm 2.19$ & $0.14 \pm 0.11$ & $0.53 \pm 0.16$ & $0.81 \pm 0.11$ & $2.18 \pm 0.73$ \\
\hline \multirow{2}{*}{$\mathrm{NO}_{3} / \mathrm{N}(\mu \mathrm{M})$} & $2.50-7.27$ & $2.36-11.99$ & $9.04-33.21$ & $2.58-4.64$ & $2.95-11.08$ & $5.71-10.80$ \\
\hline & $5.03 \pm 1.84$ & $5.79 \pm 3.02$ & $19.66 \pm 7.27$ & $3.69 \pm 0.60$ & $5.67 \pm 3.17$ & $7.97 \pm 1.72$ \\
\hline \multirow{2}{*}{$\mathrm{TN} / \mathrm{N}(\mu \mathrm{M})$} & $31.50-69.93$ & $18.21-59.93$ & $13.07-49.79$ & $21.93-56.64$ & $29.07-74.21$ & $33.62-53.13$ \\
\hline & $46.84 \pm 11.27$ & $36.47 \pm 16.57$ & $25.91 \pm 13.70$ & $47.57 \pm 9.49$ & $50.87 \pm 15.28$ & $41.53 \pm 6.14$ \\
\hline \multirow{2}{*}{$\mathrm{PO}_{4} / \mathrm{P}(\mu \mathrm{M})$} & $0.01-0.64$ & $0.01-0.69$ & $0.01-.090$ & $0.01-0.48$ & $0.17-1.63$ & $0.22-0.47$ \\
\hline & $0.29 \pm 0.19$ & $0.25 \pm 0.25$ & $0.40 \pm 0.31$ & $0.13 \pm 0.15$ & $0.79 \pm 0.48$ & $0.37 \pm 0.09$ \\
\hline \multirow{2}{*}{$\mathrm{TP} / \mathrm{P}(\mu \mathrm{M})$} & $0.68-1.14$ & $0.85-5.48$ & $0.68-1.65$ & $0.91-1.71$ & $1.14-7.37$ & $1.18-2.51$ \\
\hline & $0.91 \pm 0.15$ & $2.63 \pm 1.66$ & $1.21 \pm 0.31$ & $1.48 \pm 0.23$ & $2.90 \pm 1.84$ & $1.83 \pm 0.50$ \\
\hline \multirow{2}{*}{$\mathrm{SiO}_{4} / \mathrm{Si}(\mu \mathrm{M})$} & $0.78-26.47$ & $3.88-15.26$ & $11.29-30.43$ & $6.29-30.60$ & $4.57-19.22$ & $6.40-17.86$ \\
\hline & $10.66 \pm 7.22$ & $7.00 \pm 4.07$ & $20.15 \pm 5.49$ & $13.57 \pm 7.67$ & $10.90 \pm 5.32$ & $12.42 \pm 4.04$ \\
\hline \multirow{2}{*}{$\mathrm{Chl}-\mathrm{a}\left(\mu \mathrm{gl}^{-1}\right)$} & $1.55-4.77$ & $0.38-5.24$ & $0.48-1.76$ & $0.85-4.93$ & $2.22-6.96$ & $1.92-3.30$ \\
\hline & $3.28 \pm 1.13$ & $2.06 \pm 1.67$ & $0.92 \pm 0.49$ & $2.32 \pm 1.38$ & $4.27 \pm 1.59$ & $2.58 \pm 0.45$ \\
\hline \multirow{2}{*}{$\mathrm{SPM}\left(\mathrm{mgl}^{-1}\right)$} & $22.50-27.40$ & $18.80-34.40$ & $10.22-29.40$ & $15.90-36.30$ & $23.50-30.60$ & $17.85-30.16$ \\
\hline & $25.15 \pm 1.88$ & $29.60 \pm 4.70$ & $20.98 \pm 6.01$ & $28.55 \pm 6.99$ & $26.93 \pm 2.52$ & $26.24 \pm 2.81$ \\
\hline
\end{tabular}



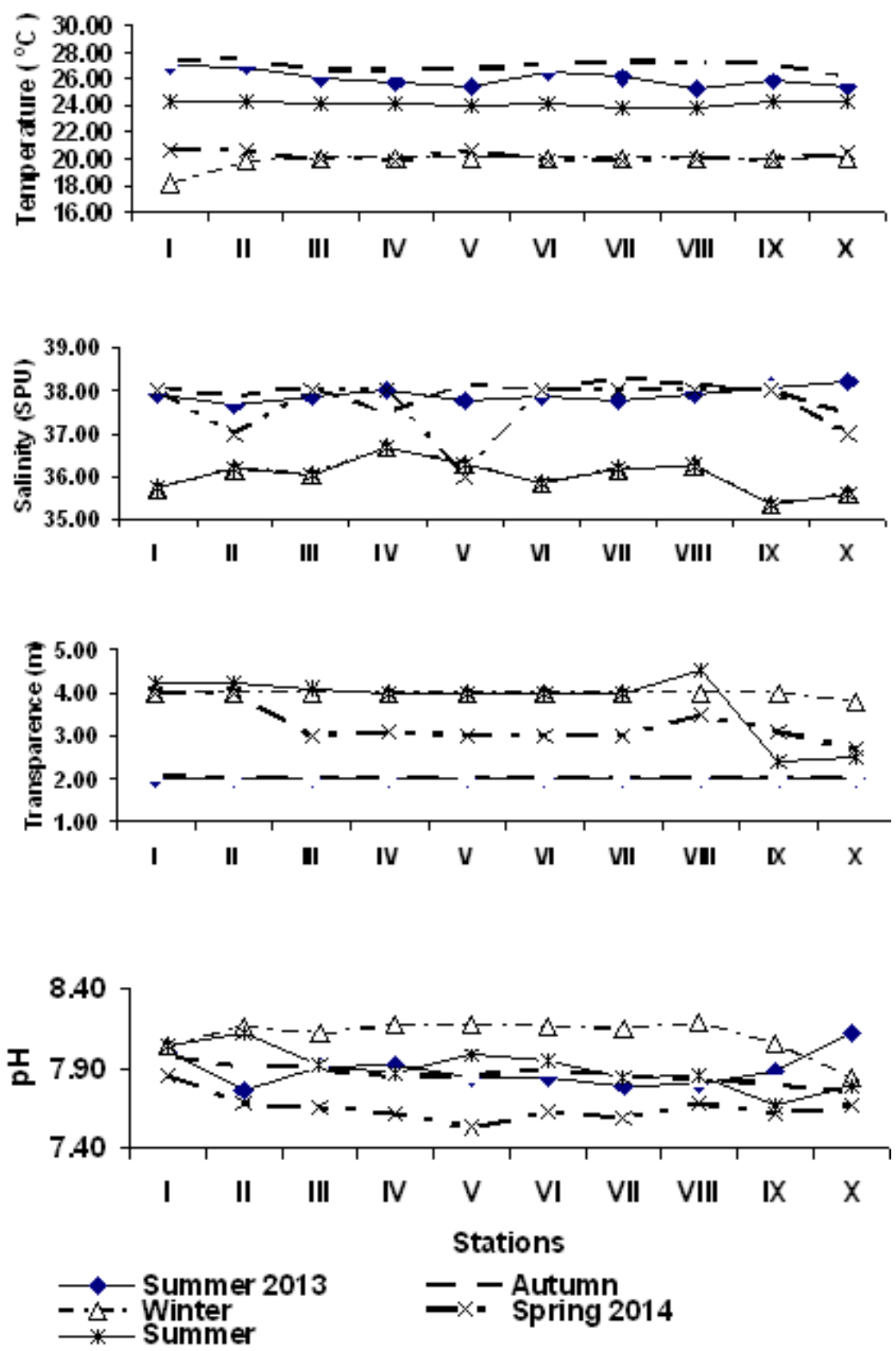

Fig. 2. Regional and seasonal variations of Temperature $\left({ }^{\circ} \mathrm{C}\right)$, Salinity (PSU), Transparence (m) and pH values in Alexandria coastal zone water during 2013-2014.

\subsection{Biochemical Oxygen Demand $\left(B^{\circ} D_{5}\right)$}

A five-day biochemical oxygen demand (BOD5) concentration was measured regularly for the seawater samples from the study area. As shown in Table1 and Figure3, the highest concentration was recorded at station III; it reached to $6.40 \mathrm{mg} / \mathrm{l}$ in winter (December 2013). The lowest value was recorded in summer (September 2013); it reached to $0.31 \mathrm{mg} / \mathrm{l}$. Whole stations in the study area considered no polluted area.

\subsection{Chemical Oxygen Demand (COD)}

The equivalent amount of oxygen needed to break down organic matter under strong oxidizing agents is known as
Chemical Oxygen Demand or COD. A strong oxidizing agent is added to quickly break down organic material. The process is much faster to perform than BOD testing since an incubation period is not required. COD, like BOD, is only an approximation of the natural degradation of organic materials in nature. The harsh chemicals may break down more of the organic material than a natural process. Hence, COD is usually greater than the BOD. Table1 and Figure 3 showed the level of COD along the study area from Abu Qir Bay (Station I) to the Eastern Harbor (Station X). The concentrations of the COD revealed seasonal and regional variations. It ranged between a minimum of $2.86 \mathrm{mg} \mathrm{O}_{2} / 1$ in winter (December 2013) at station IX and a maximum of $12.50 \mathrm{mg} \mathrm{O}_{2} / 1$ in summer (June 2014) at station $X$. The annual average value of the COD was 
$6.96 \pm 1.20 \mathrm{mg} \mathrm{O}_{2} / 1$. The main values of COD in the study area were approximately within those recorded for El-Mex Bay and El-Dekhaila Harbor; around $5.8 \mathrm{mg} / \mathrm{l}$ by Tayel et al. (1996)[17]. The present average value of COD in the present study was doubled that recorded by Aboul Kassim, (1987) [18] $(2.29 \mathrm{mg} / \mathrm{l})$ and similar to that reported by Faragallah et al.
(2009) [19] (4.73 $\pm 2.85 \mathrm{mg} / \mathrm{l})$. The present data are corresponding to recommended permissible levels of the Egyptian Law 4/1994 that regulates discharge of wastewaters in coastal environments. Permissible Level EEAA (EEAA= Egyptian Environmental Agency Affairs) BOD (mg O2/L) = 60 and $\mathrm{COD}(\mathrm{mg} \mathrm{O} 2 / \mathrm{L})=100$
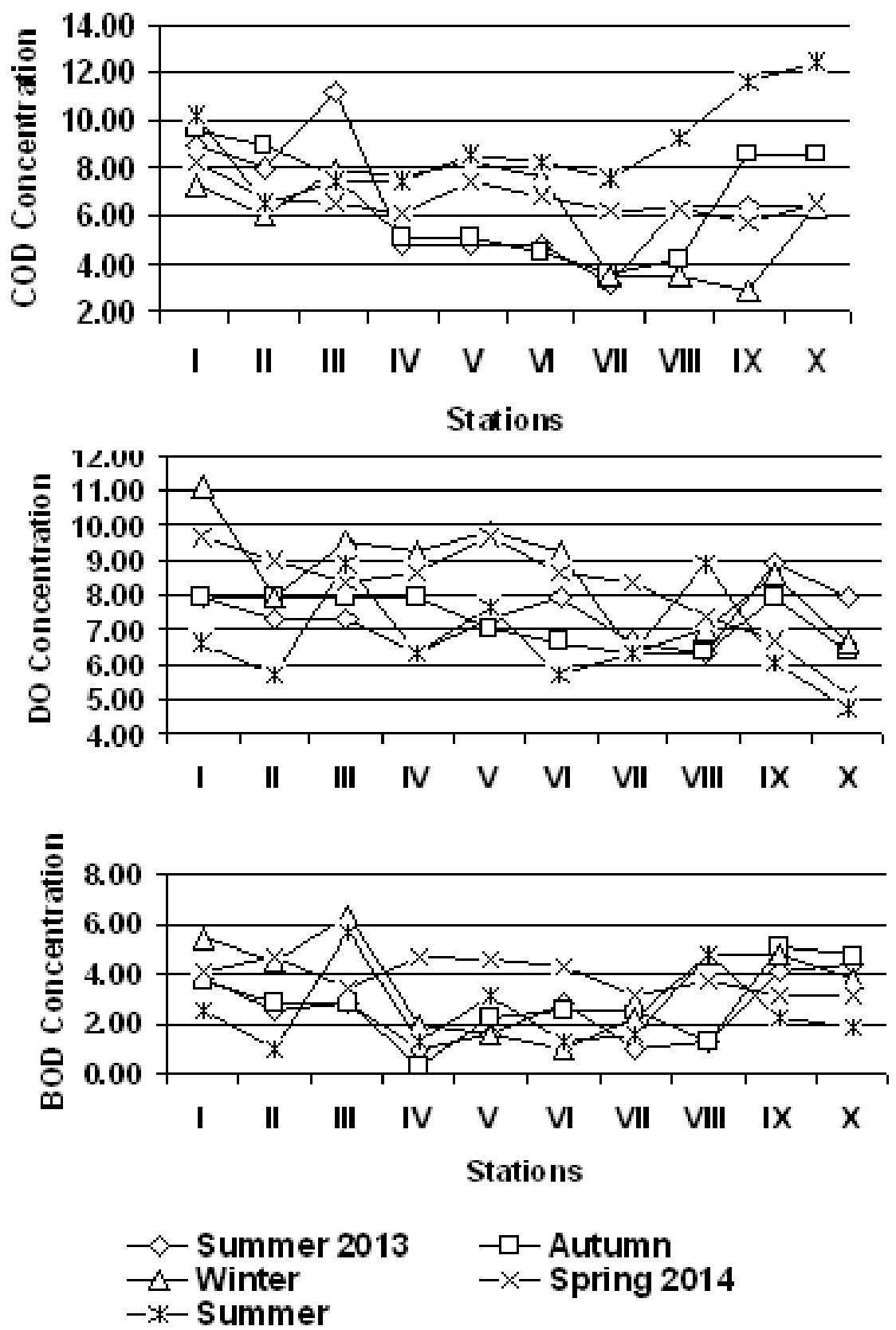

Fig. 3. Regional and seasonal variations of Chemical Oxygen Demand (COD, mg/l), Dissolved Oxygen (DO, mg/l) and Biological Oxygen Demand (BOD, mg/l) in Alexandria coastal zone water during 2013-2014.

\subsection{Suspended Particulate Matter (SPM)}

Suspended matter consists of lithogenic material and biogenic parts including of plankton and detritus, the value of total suspended matter content (Figure4) was fluctuated between minimum value of $10.22 \mathrm{mg} \mathrm{l}^{-1}$ at station II in winter and maximum value of $36.30 \mathrm{mg} \mathrm{l}^{-1}$ at station $\mathrm{I}$ in summer. The annual mean values of SPM ranged from $19.90 \pm 3.30 \mathrm{mg}$
$1^{-1}$ at station VII and $30.16 \pm 4.16 \mathrm{mg} \mathrm{l}^{-1}$ at station IX. In general, the values of TSM in the coastal water revealed high levels of organic and inorganic matter produced by living organisms as well as terrigenous particles transported by land run off. The high levels of total suspended matter were observed at Abu Qir bay and Eastern Harbor (stations I and IX). Their highest values were directly affected on the levels of transparency. 

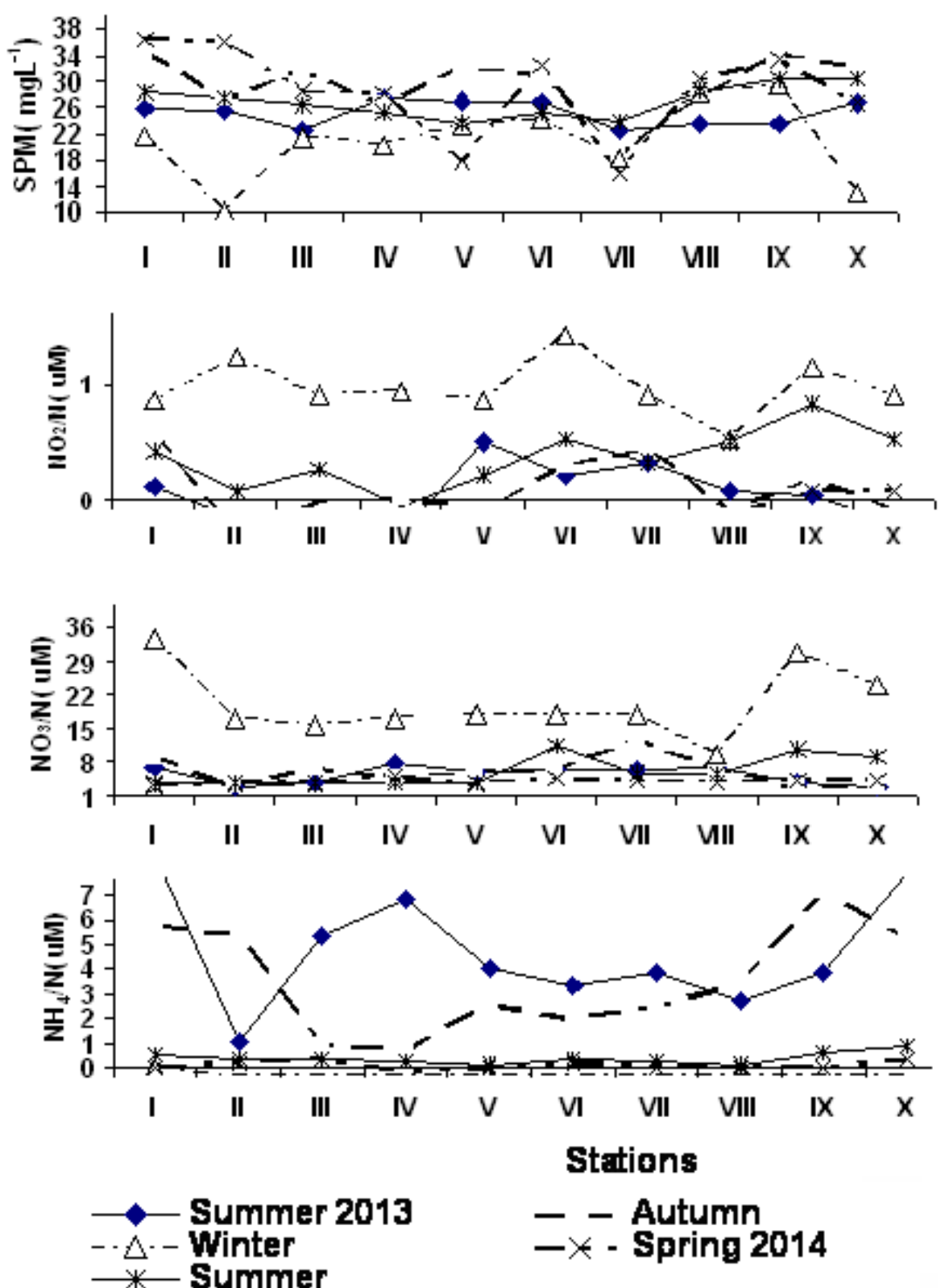

Fig. 4. Regional and seasonal variations of $\mathrm{SPM}(\mathrm{mg} / \mathrm{l}), \mathrm{NO}_{2} / \mathrm{N}, \mathrm{NO}_{3} / \mathrm{N}$, and $\mathrm{NH}_{4} / \mathrm{N}(\mu \mathrm{M})$ in Alexandria coastal zone water during $2013-2014$.

\section{Nutrient Salts}

\subsection{Dissolved Inorganic Nitrogen (DIN)}

Ammonium is the major nitrogenous product of the bacterial decomposition of organic matter containing nitrogen, and is an important excretory product of invertebrates and vertebrates. As for the utilization of nitrogenous materials, ammonium is the preferred inorganic source because of its ease uptake and incorporation into amino acids (N-assimilation). The present study showed that, winter2013, spring and summer 2014 (Figure 4) have low levels of $\mathrm{NH}_{4} / \mathrm{N}$ $(<1.00 \mu \mathrm{M})$. Faragallah (1995)[19] observed low concentration of $\mathrm{NH}_{4} / \mathrm{N}$ during winter in the eastern harbor
$(3.37 \mu \mathrm{M})$ and respect this to promotion of nitrification due to violation of the water as a result of wave and wind action prevailing in this season. Also Madkour et al. (2007) [20] pointed out that March has the lowest value of $\mathrm{NH}_{4} / \mathrm{N}$ during 2002. In our studied area, June and September 2013 have high concentration of $\mathrm{NH}_{4} / \mathrm{N}$ (ranged; 3.98 - $5.16 \mu \mathrm{M}$ ). Madkour et al. (2007) [20] respect this to the stratification and the effect of the rise in water temperature which may induce the mineralization from the sediment, decomposition rate of sewage and other organic wastes.

The distribution of $\mathrm{NO}_{2} / \mathrm{N}$ characterized by the low level (ranged; $0.01-1.82 \mu \mathrm{M}$ ). The average values of $\mathrm{NO}_{2} / \mathrm{N}$ were similar comparing with those recorded in the previous studies; it was $0.95 \mu \mathrm{M}[18]$ and $0.48 \mu \mathrm{M}[19]$. 
Nitrate form is generally considered as the most stable and predominant inorganic nitrogen compound in oxygenated sea water. Nitrate concentration ranged between 2.50 and 33.21 $\mu \mathrm{M}$. The distribution of $\mathrm{NO}_{3} / \mathrm{N}$ (Figure4) showed that the concentration during June2013 is similar to that of June 2014. Also the distribution of $\mathrm{NO}_{3} / \mathrm{N}$ through the study period is mostly similar to that of $\mathrm{NH}_{4} / \mathrm{N}$. These refer to the fact that the rate of nitrification is mostly similar to that of denitrification, or due to the oxidation of ammonia to nitrite and nitrate either chemically or biologically.

Dissolved inorganic nitrogen content (the sum of ammonium, nitrite and nitrate) in the costal zone water of Alexandria is relatively low. The absolute values of ammonium, nitrite and nitrate revealed wide variation as shown in Table1 and Figure4. Ammonium was fluctuated between $0.10 \mu \mathrm{M}$ (at all the stations during winter) and 8.97 $\mu \mathrm{M}$ (station I in summer 2014). Nitrite ranged between 0.01 $\mu \mathrm{M}$ in March at station IV and 1.82 in December 2013 at station VI, the highest annual mean value was recorded in winter $(1.36 \pm 0.24 \mu \mathrm{M})$ while nitrate distribution varied from $2.36 \mu \mathrm{M}$ in September (station IX) to $33.21 \mu \mathrm{M}$ in December (station I).The regional variations of dissolved inorganic nitrogen showed that, the minimum mean concentration was $0.1 \mu \mathrm{M}$ for $\mathrm{NH}_{4} / \mathrm{N} ; 0.01 \mu \mathrm{M}$ for $\mathrm{NO}_{2} / \mathrm{N}$ and $2.36 \mu \mathrm{M}$ for $\mathrm{NO}_{3} / \mathrm{N}$ were recorded at all stations and stations IX and IV, respectively. On the other hand, the maximum mean values of $\mathrm{NH}_{4} / \mathrm{N}(8.97 \mu \mathrm{M}) ; \mathrm{NO}_{2} / \mathrm{N}(1.82 \mu \mathrm{M})$ and $\mathrm{NO}_{3} / \mathrm{N}(33.21 \mu \mathrm{M})$ were found at stations I; I and VI, respectively. The relatively high concentration of $\mathrm{NH}_{4} / \mathrm{N}, \mathrm{NO}_{2} / \mathrm{N}$ and $\mathrm{NO}_{3} / \mathrm{N}$ may be due to the amounts of drainage wastewater from the surrounding area, which are contaminated by anthropogenic material. The concentrations of $\mathrm{NH}_{4} / \mathrm{N}$ and $\mathrm{NO}_{3} / \mathrm{N}$ decreased in spring and summer seasons may be related to the high growth of phytoplankton. The relative decrease of $\mathrm{NH}_{4} / \mathrm{N}, \mathrm{NO}_{2} / \mathrm{N}$ and $\mathrm{NO}_{3} / \mathrm{N}$ in summer and spring may be as a result of nutrients consumption by phytoplankton. This illustrated as a result of the high levels of chlorophyll-a concentrations during these seasons, it ranged from $4.27 \pm 1.59 \mu \mathrm{gl}^{-1}$ in June 2014 and decreased to lowest level in winter $\left(0.92 \pm 0.49 \mu \mathrm{gl}^{-1}\right.$, December2013).

The present data reflecting similarity between the rate of nitrification and denitrification processes. The average value of $\mathrm{NO}_{3} / \mathrm{N}$ concentration $(7.97 \pm 1.72 \mu \mathrm{M})$ was slightly increased than the average content of $\mathrm{NH}_{4} / \mathrm{N}(2.18 \pm 0.73 \mu \mathrm{M})$, while the concentration of $\mathrm{NO}_{2} / \mathrm{N}$ decreased ten folds than those recorded for $\mathrm{NO}_{3} / \mathrm{N}$ and four folds for $\mathrm{NH}_{4} / \mathrm{N}$. Based on these results, the abundance of nitrogen species in the study area is principally in the order $\mathrm{NO}_{3} / \mathrm{N}>\mathrm{NH}_{4} / \mathrm{N}>\mathrm{NO}_{2} / \mathrm{N}$. This reflects the uptake preferable of the inorganic nitrogen species by phytoplankton organisms in their $\mathrm{N}$-assimilation. This could be confirmed by the relationship between the concentration of both $\mathrm{NO}_{3} / \mathrm{N}$ and $\mathrm{NH}_{4} / \mathrm{N}$ with the values of Chl-a, respectively.

$$
\begin{aligned}
& \text { Chl-a }=3.396-0.095 \mathrm{NO}_{3} / \mathrm{N} \mathrm{r}=0.383 \text { at } P<0.05 \mathrm{n}=50 \\
& \text { Chl-a }=2.185+0.213 \mathrm{NH}_{4} / \mathrm{N} \mathrm{r}=0.303 \text { at } P<0.05 \mathrm{n}=50
\end{aligned}
$$

\subsection{Phosphorus Compounds}
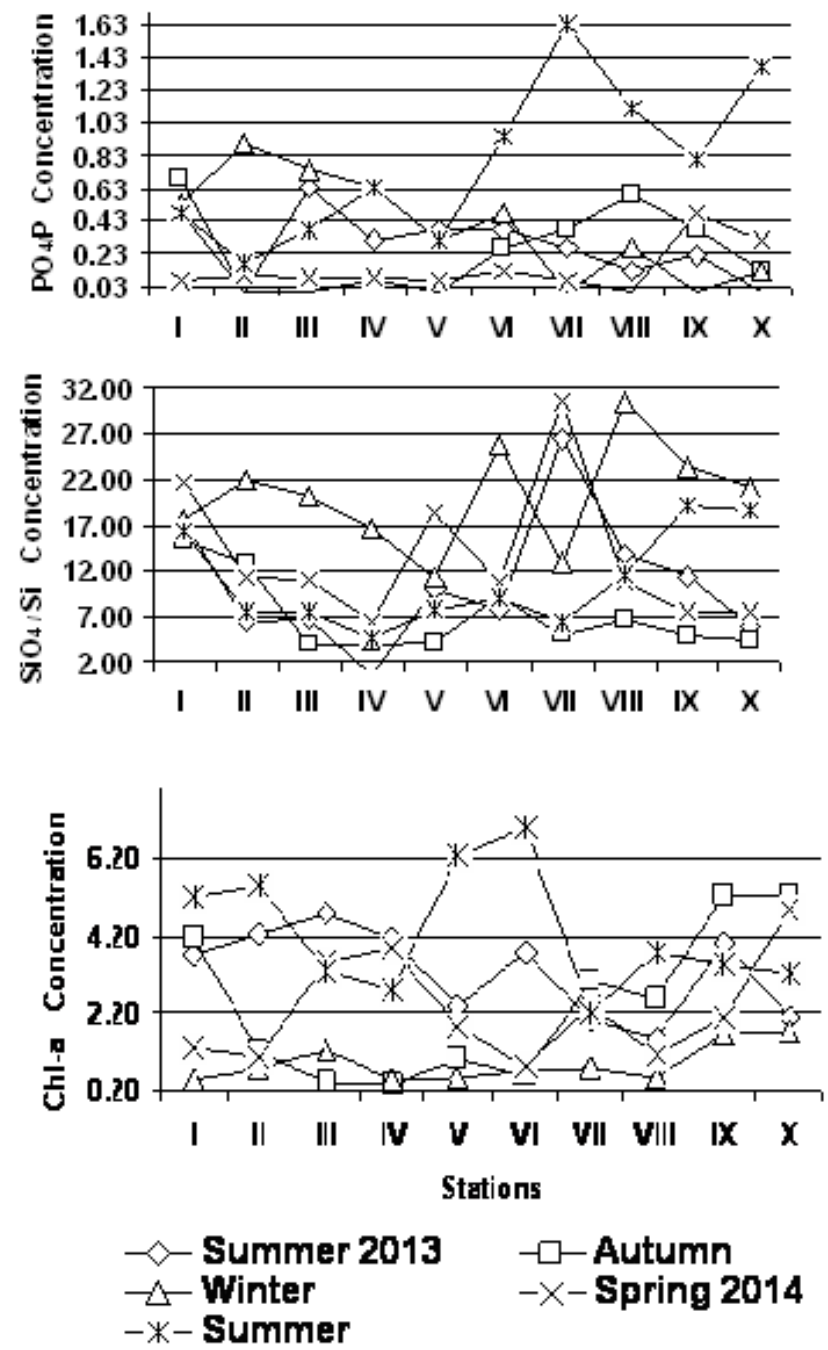

Fig. 5. Regional and seasonal variations of Reactive phosphate $\left(\mathrm{PO}_{4} / \mathrm{P}, \mu \mathrm{M}\right.$ Silicate $\left(\mathrm{SiO}_{4} / \mathrm{Si}, \mu \mathrm{M}\right)$ and Chlorophyll-a $(\mathrm{Chl}-\mathrm{a}, \mu \mathrm{g} / \mathrm{l})$ in Alexandria coastal zone water during 2013-2014.

The mean concentration of $\mathrm{PO}_{4}-\mathrm{P}$ (Table1 and Figure5) reveled that, the lowest value $(0.01 \mu \mathrm{M})$ was recorded at station II in all seasons except winter (December 2013) and the highest concentration of $\mathrm{PO}_{4} / \mathrm{P}$ in the study area was recorded in summer $2014(1.63 \mu \mathrm{M})$ and $(1.37 \mu \mathrm{M})$ at stations VII and X, respectively, this may be related to the wastewater discharge. A significant negative correlation between salinity and $\mathrm{PO}_{4} / \mathrm{P}$ was found, $(r=-0.370)$. The reverse relationship between salinity and $\mathrm{PO}_{4}-\mathrm{P}$ can be interpreted on the basis of the reactive phosphate is allochthonous.

$$
\text { Salinity }=37.51-1.132 * \mathrm{PO}_{4} / \mathrm{P} \mathrm{r}=0.370 \text { at } P<0.05 \mathrm{n}=50 \text {,] }
$$

Total phosphorus concentration in the coastal zone of Alexandria showed a wide range of variation (Table1). The absolute value of total phosphorus fluctuated between 0.68 $\mu \mathrm{M}$ at station VIII in summer and station VII in winter 2013 and $5.84 \mu \mathrm{M}$ at station VIII in September. Generally, the concentration of total phosphorus was relatively high in 
autumn $2013(2.63 \pm 1.66 \mu \mathrm{M})$ and summer $2014(2.90 \pm 1.84$ $\mu \mathrm{M})$, this may be related to the amounts of wastewater drainage into the study area.

\subsection{Reactive Silicate (SiO4)}

Silicate is one of the major constituents in the sea water. It is a good indicator of fresh water dispersion and of the potential for diatom [21]. The seasonal distribution of silicate concentration in the area of study water showed a wide range of variation (Table1 and Figure5). It ranged from $0.78 \mu \mathrm{M}$ in June 2013 (station IV) to $30.43 \mu \mathrm{M}$ in December (StationVIII). The highest mean content of silicate was found in winter 2014 $(20.15 \pm 5.49 \mu \mathrm{M})$ and decreases to lowest level in autumn $(7.00 \pm 4.07 \mu \mathrm{M})$. The lower silicate was recorded during summer, autumn, spring 2013 and summer 2014; this may be due to the high level of phytoplankton growth (Chl-a was 3.28 $\pm 1.13 ; 4.27 \pm 1.59 \mathrm{~g} \mathrm{l}^{-1}$ in summer 2013 and 2014 and $2.06 \pm$ $1.67 \mu \mathrm{g} \mathrm{l}^{-1}$ in spring 2014, respectively). The present results are the opposite than that reported by Faragallah et al. (2009) [19] in the eastern harbor, their results showed high levels of $\mathrm{SiO}_{4}$ in summer and spring (chemical precipitation of silicate occurred which was retained to the sediment and did not diffuse to the water column). In general, the results revealed that the annual mean value of silicate was $12.42 \pm 4.04 \mu \mathrm{M}$ along the study area, this value increased four times than those reported by Faragallah et al. (2009)[19] in the eastern harbor (an average $3.45 \pm 2.7 \mu \mathrm{M}$ ). The average concentration of $\mathrm{SiO}_{4}$ $(12.42 \pm 4.04 \mu \mathrm{M})$ was higher than that of the other nutrient salts. This means that $\mathrm{SiO}_{4}$ is not a limiting factor of phytoplankton growth in the study area. The present level of silicate (average; $12.42 \pm 4.04 \mu \mathrm{M}$ ) was higher to that recorded by Abdel-Halim and Khairy (2007) [22] at the eastern harbor. On the other hand, the data was similar to those recorded by Dorgham et al. (2004) [23] (9.03 $\mu \mathrm{mole} / \mathrm{l})$, in the western Harbor, and it was markedly lower to that reported by Abdel Aziz et al. (2001) [24] (16.74 $\mu \mathrm{M})$ in Abu Qir bay and $49.52 \mu \mathrm{mole} / 1$ in El-Dekhaila harbor [25]. Although the drainage waters have been reported as the principal source of silicate in the area and play a significant part in its spatial and temporal distribution, it was found that phytoplankton growth was actually regulating the silicate level [23]. The results showed relationship between phytoplankton and silicate content, this is confirmed with the negative correlation between silicate and Chl-a concentration $(r=-0.342)$.

$$
\text { Chl-a }=3.645-0.081 * \mathrm{SiO}_{4} \mathrm{r}=-0.342 \text { at } P<0.05 \mathrm{n}=50
$$

The same observation was found by Abdel-Halim and Khairy (2007) [22]. The regional variations of silicate content were related to the amounts of drainage water discharged.

\subsection{Chlorophyll-a (Chl-a)}

Chlorophyll-a concentration is considered as a good indicator of the phytoplankton biomass [26], and it is used as a trophic state indicator. The distribution of Chl-a in the investigated area during the year 2013-2014 is presented in Table1 and Figure5. The mean concentration of Chl-a was exhibited lower value at station IV $\left(0.38 \mu \mathrm{g} 1^{-1}\right)$ in autumn 2013, while the highest value at station VI $\left(6.96 \mu \mathrm{g} \mathrm{l}^{-1}\right)$ in June 2014. The results as shown in Table1 revealed high concentration of Chl-a in hot seasons, ranged from $2.06 \pm 1.67$ $\mu \mathrm{g} \mathrm{l^{-1 }}$ to $4.27 \pm 1.59 \mu \mathrm{g} \mathrm{l^{-1 }}$. Faragallah et al. (2009) [19] showed that most days during autumn and winter mainly had levels of Chl-a lower than that recoded during spring and summer. The results of Chl-a concentration during the period of study was lower, the average value decreased six folds $\left(2.58 \pm 0.45 \mu \mathrm{g} \mathrm{l}^{-1}\right)$ than those recorded during 2008 and 2009 $\left(13.60 \pm 18.85 \mu \mathrm{g} \mathrm{l}^{-1}\right)[19,27]$. The present data of Chl-a was in agreement with that of phytoplankton biomass collected from the same sites [27]. Also, the results indicated relatively high concentration of Chl-a in Alexandria coastal zone comparing with that reported by Ignatiades et al. (1992)[28] in the north and eastern Mediterranean sea (0.01-0.15 $\left.\mu \mathrm{g} \mathrm{l}^{-1}\right)$ and higher than that recorded in Aegean Sea; 0.10-0.80 $\mu \mathrm{g} \mathrm{l}^{-1}$ [29]. In general, the high values of chlorophyll-a in the investigated area are undoubtedly due to the rich supply of DIN, reactive silicate and reactive phosphate, these nutrient salts contribute for the growth of phytoplankton expressed in high levels of Chl-a. The simple regression analysis between $\mathrm{Chl}-\mathrm{a}$ and both $\mathrm{PO}_{4}$ and $\mathrm{NO}_{3}$ indicated a poor linear relationship $(r=0.213$ for $\mathrm{PO}_{4}$ and $r=0.308$ for $\mathrm{NO}_{3}$ ). This may be related to the rapid utilization of $\mathrm{NO}_{3}$ and $\mathrm{PO}_{4}$ by phytoplankton [30]. On the other hand, there is a significant positive relationship between silicate and Chl-a content.

$$
\text { Chl-a }=3.645-0.081 * \mathrm{SiO}_{4} r=0.341 \text { at } P<0.05, \mathrm{n}=50 \text {. }
$$

This may reflect the role of silicate content in the growth of phytoplankton and the biological processes.

\subsection{Nitrogen/Phosphorus ratio (N/P ratio)}

Since the observation of Redfield [31] that marine phytoplankton contains a molecular C: N: P ratio of 106:16:1 (50:7:1 by weight), the use of elemental ratios has become widespread in marine and freshwater phytoplankton studies. Deviation from the Redfield ratio has been used as an indication of which nutrient is limiting, especially when nutrient concentrations are low to moderate. For example if $\mathrm{N}: \mathrm{P}>>16: 1, \mathrm{P}$ is assumed to be limiting. Nutrient ratios have value in determining potential nutrient limitation, but nutrient concentrations must also be considered to determine actual nutrient limitation [32]. Seasonal variations of Minimum, Maximum and mean values of N/P ratios in Alexandria coastal zone water during 2013-2014 are shown in Figure 6. With some exception the calculated values of N:P ratio were higher than that of Redfield ratio (16:1)[33], its higher average values were 77.5,197,103 and 86 for summer, autumn, winter 2013 and spring 2014,respectively. These values indicated that nitrogen is the limiting factor for phytoplankton growth in the study area during these seasons. In contrast, N: P ratio was lower than that of Redfield ratio during summer 2014 (9.0) indicating that phosphorus is the limiting factor. According to the previous studies, extreme variation of N/P ratio is common along the Egyptian Mediterranean coast, particularly at areas 
exposed to land based runoff [23]. The results recorded by Chraudani and Vighi (1978) [34] found that marine algae are P-limited at N:P ratio $>6$ and $\mathrm{N}-$ limited at ratio $<4.5$; in range of $4.5-6$, the two nutrients are near their optimal assimilative proportion. In the present study, N/P ratio ranged between very low value $<4.5$ ( $\mathrm{N}$ limited) in summer 2014 and very high value 652 (P limited) in autumn 2013. Very high values of N/P ratio were recorded at most period of study, this consideration shows that Phosphorus was limiting factor in the area of study. Also, the ratio average value in the study region (9-197) indicates that nitrogen and phosphorus are removed from water at almost constant proportions. This observation was true by the studies which carried out by Aboul-Kassim (1987) and Faragallah (1995) [18, 35] in the Eastern Harbor.

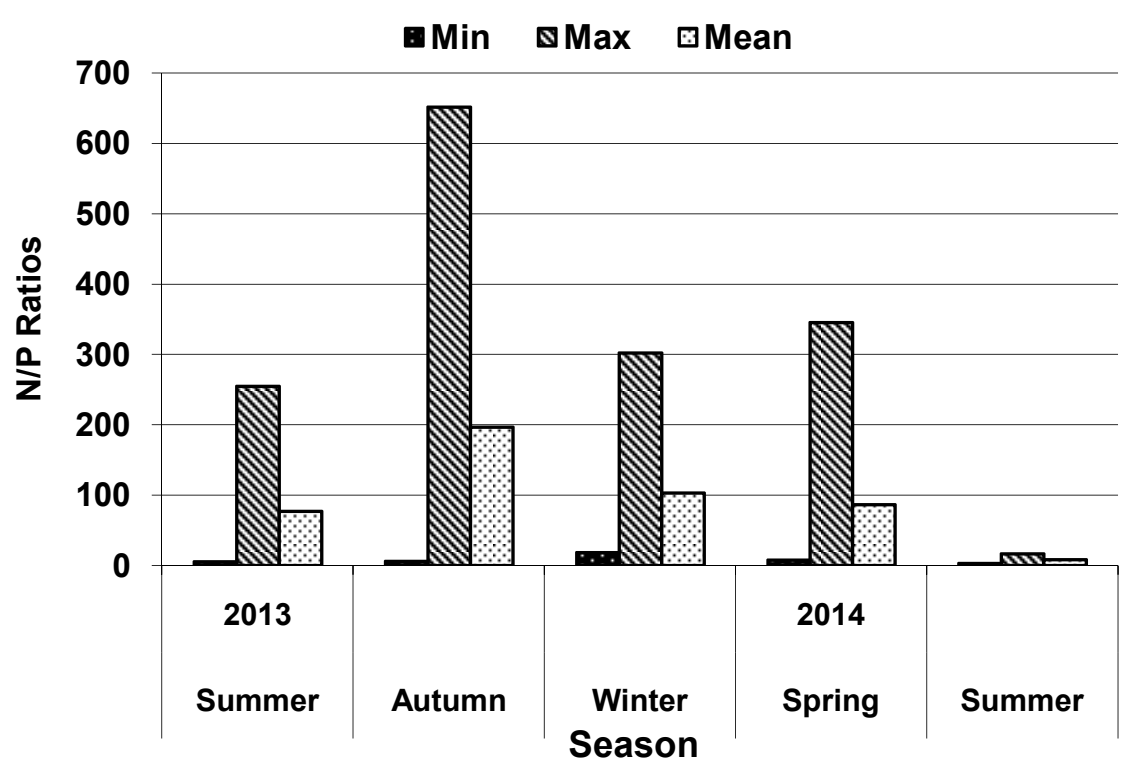

Fig. 6. Seasonal variations of Min, Max and mean values of N/P ratios in Alexandria coastal zone water during 2013-2014.

\subsection{Eutrophication Index}

Trophic state index (TSI) is a valuable tool in determining the condition of marine water or in comparing the present condition to the past. Several studies considered that the concentration of nitrate, reactive phosphate, chemical oxygen demand, chlorophyll-a and primary production are important factors to calculate the main indices of eutrophication in marine water $[16,36]$. The water quality criteria for marine fisheries of China were $0.015,0.100$ and $3.00 \mathrm{mg} / \mathrm{l}$ for $\mathrm{PO}_{4}-\mathrm{P}$, $\mathrm{NO}_{3}-\mathrm{N}$ and $\mathrm{COD}$, respectively [16]. In the present study, the concentration of COD revealed wide variations than those reported by Tomotoshi (1972) [16], the average values were; $0.012 \mathrm{mg} / 1$ for $\mathrm{PO}_{4}-\mathrm{P} ; 0.112 \mathrm{mg} / 1$ for $\mathrm{NO}_{3}-\mathrm{N}$ and $6.96 \mathrm{mg} / \mathrm{l}$ for COD. In general, the values of eutrophication index in the studied area were more than one (2.08) during the five seasons of the study, which were characterized eutrophic condition. The present data of eutrophication index showed lower values comparing with that reported by Zaghloul (1996) [36].

Table 2 showed the average values of nutrients in the present study comparing to other Egyptian waters. It can be observed that the levels of nutrient salts recorded in the present study were comparable with the previous studies. In addition, the level of nutrients indicated that Abu-Qir Bay (station I) and eastern Harbor (station X) are in the eutrophic state according to the standard levels reported by Franco (1983)[37].

\section{Conclusion}

Information of this study constitutes a baselines of hydrographic condition, nutrient salts and chlorophyll-a along Alexandria coastal area. The amounts of the dissolved inorganic nitrogen forms followed the sequence: $\mathrm{NO}_{3}-\mathrm{N}>$ $\mathrm{NH}_{4}-\mathrm{N} \geq \mathrm{NO}_{2}-\mathrm{N}$, showing the high production rate of $\mathrm{NO}_{3}-\mathrm{N}$ than the rate consumption comparing with the other inorganic nitrogen forms $\left(\mathrm{NH}_{4}-\mathrm{N}, \mathrm{NO}_{2}-\mathrm{N}\right)$. The results also showed that, the high content of nitrogen and phosphorus were found mainly in the organic forms. This observed from the difference between the total nitrogen and the sum of dissolved inorganic nitrogen and the difference between total phosphorus and reactive phosphate. As a result of high levels of nutrient salts, reflected by relatively high concentration of chlorophyll $a$ (reached to $6.96 \mathrm{gg}^{-1}$ in June 2014. A significant positive relationship was found between silicate and Chl-a content. ( $r=0.341)$, this may reflect the role of silicate content in the growth of phytoplankton and the biological processes.

\section{References}

[1] Abd-Alla, M. (1993).Concentration of mercury in fresh, brackish and saline waters in Alexandria region. M.Sc. Thesis, Institute of Graduate Studies and Research, Alexandria Univ., Egypt, 145 pp 
[2] Nasr, S. M. (1995).Geochemistry and granulometric normalization for heavy metals in the bottom sediments off Alexandria, Egypt. Proceeding of the 2ndConference on the Mediterranean Coastal Environment. MEDCOAST 95, Tarragona, Spain, 1473-1481.

[3] Saad M.A.H.; Mccomas, S.R., \& Eisenreich, S.J., (1985). Metals and chlorinated hydrocarbons in surficial sediments of three Nile delta lakes, Egypt. Water, Air and Soil Pollution, 24:27-39.

[4] Said M.A., Ennet P., Kokkila T. \& Sarkkula J. (1995). Modeling of transport processes in Abu Qir Bay, Egypt, Medcoast 95, October 24- 27, Tarragona, Spain

[5] Hassan M. A. (1996). Remote sensing and geographical informat ion system for environmental analysis and planning of a coastal urban area west of Alexandria, M.Sc. thesis; Alexandria University, 195p.

[6] Shriadah MA. \& Emara HI. (1996). Heavy metals (iron, manganese, nickel, cadmium, and lead) in the sediments from the Eastern Harbor and El-Mex Bay of Alexandria, Egypt. Proceedings of the sixth International Conference on Environmental Protection, 21-23 May, Alexandria, pp. 916-27.

[7] Fahmy, M. A., Tayel, F. T., \& Shriadah, M. A. (1997). Spatial and seasonal variations of dissolved trace metals in two contaminated basins of the coastal Mediterranean Sea, Alexandria, Egypt. Bulletin. Faculty of Science. Alexandria University, 37, 187-198.

[8] Said, M. A., El-Deek, M. S., Mahmoud, T. H., \& Shriadah, M. A. (1994). Effect of pollution on the hydrochemical characteristicsof different water types in El-Max Bay area, west of Alexandria, Egypt. Acta Adriatica, 34, 9-19.

[9] Masoud MS., Mahmoud ThH. \& Abdel-halim AM. (2001). Chemical studies of El-Mex Bay, Alexandria. Proceeding of the Second Conference and Exhibition for Life and Environment, 3-5 April, Alexandria, pp. 339-60.

[10] Samir, A. M., \& El-Din, A. B. (2001). Benthic foraminiferal assemblages and morphological abnormalities as pollution proxies in two Egyptian bays. Marine Micropaleontology, 41, 193-227.

[11] Shreadah, M. A., Said, T. O., Othman, I. M., Fathallah, E. M., \& Mahmoud, M. E. (2012). Polychlorinated biphenyls and chlorinated pesticides in sediments along the semi-closed areas of Alexandria, Egypt. Journal of Environmental Protection, 3, 141-149.

[12] Abdel Ghani, S. A., El Zokm, G., Shobier, A. H., Said, T. O., \& Shreadah,M. A. (2013). Metal pollution in surface sediments of Abu-Qir Bay and the Eastern Harbour of Alexandria, Egypt. Egyptian Journal of Aquatic Research, 39, 1-12.

[13] FAO (1975). Manual of methods in aquatic environment research. FAO Fisheries Technical Paper, No. 137, 238 pp.

[14] Grasshoff, K. (1979). Methods of sea water analysis with contributions by T. Almgreen; R. Dowson; M. Ehrhaedt; S.H. Fonselius; B. Josefsson, F. Koroleff, K. Kremling. Aufl. Weinheim. New York Verlag Chemie. 317 pp.

[15] Strickland, J. \& Parsons, T. (1972). A practical handbook of sea water analysis. Bulletin of the Fisheries Research Board of Canada, 167: 310p.
[16] Tomotoshi Okaichi (1972). In IOC/Westpac. Workshop. Penang.Malaysia, 26-29 Nov., 1991, Report, No.79, Annex III-P167.

[17] Tayel, F.T.R., M.A. Fahmy \& Sheriadah M.M.A. (1996). Studies on the physico-chemical characteristics of Mex and new Dekhaila Harbors waters of Alexandria, Egypt. Egyptian Journal of Aquatic Research, (22):1:18.

[18] Aboul-Kassim, T. (1987). Cycles of carbon, nitrogen and phosphorus in the marine environments of Alexandria region. MSc. Thesis, Faculty of Science, Alexandria Univeristy, 233p.

[19] Faragallah,H.M., H.R.Z.Tadros \& M.A. Okbah (2009). Nutrient salts and chlorophyll-a during short term scale in the Eastern Harbor, Alexandria (Egypt). Egyptian Journal of Aquatic Research, 35(3), 243-250

[20] Madkour, F; Dorgham, M \& Fahmy, M. (2007). Short term scale observations on phytoplankton in the Eastern Harbour of Alexandria, Egypt. Egyptian Journal of Aquatic Research, 33(1):193-209.

[21] Fahmy, M.A., A.I.Beltagi \& Abbas M.M. (1999). Nutrient salts and Chlorophyll-a in the Egyptian Mediterranean coastal waters. MEDCAST 99- EMECS99 Joint conferences, Land-Ocean Interactions: Managing Castal Ecosystems, 9-13 November, Antalya, Turkey.

[22] Abdel-Halim, A.M. \& Khairy, H.M. (2007). Potential impact of some abiotic parameters on a phytoplankton community in a confined bay of the Eastern Mediterranean sea: eastern Harbor of Alexandria Egypt. Mediterranean Marine Science, Vol. 8/2, 49-64.

[23] Dorgham, M.M., Abdel-Aziz, N.E., El-Deeb, K.Z. \& Okbah, M.A. (2004) Eutrophication problems in the Western Harbor of Alexandria, Egypt. Oceanologia, 46 (1): 25-44.

[24] Abdel Aziz, N.E.M.; Fahmy, M.A. \& Dorgham, M.M. (2001). Hydrography, nutrient levels and plankton abundance in Abu-Qir Bay, Egypt. Mediterranean Marine Science, 2 (2): 13-17.

[25] Abdel Aziz, N.E.M.; Fahmy, M.A. \& Dorgham, M.M. (2006). water quality observations on the Dekhaila Harbour, Alexandria, Egypt. Egyptian Journal of Aquatic Research, 32 (2): 167-182.

[26] Carlson, R. E. (1977). 'Atrophic state index for lakes', Limnology Oceanography 22(2): 361-369.

[27] Mikhail's. K., Aboul Ezz, S. M. \& Okbah, M. A.(2008). Blooms of toxic microalgae and cooccurringciliates, heterotrophic and mixotrophic dianoflagellates in the eastern harbor, Alexandria (Egypt). Egyptian Journal of Aquatic Research, 34(2): 96-113

[28] Ignatiades, L., Karydis, M. \& Vounatsou, P. (1992). A possible method for evaluating oligotrophy and eutrophication based on nutrient concentration scales. Marine Pollution Bulletin, 24(5): 238-43.

[29] UNESCO. (1990). Reports and studies, No.34. Review of potentially harmful substances. Nutrients, 40pp.

[30] James, A. \& Head, P. C. (1972). 'The discharge of nutrient from estuaries and their effects on primary production', Marine pollution and sea life (Ed. By Mario Ruivo). pp. 166-90. 
[31] Redfield A C. (1958). The biological control of chemical factors in the environment. Am Sci 46:205-221.

[32] Bothwell, M. L. (1985). Phosphorus limitation of lotic periphyton growth rates: An intersite comparison using continuous-flow troughs (Thompson River system, British Columbia). Limnol. Oceanogr. 30: 527-542

[33] Redfield, A. C., Ketchum, B. H. \& Richards, F. A. (1963). The influence of organisms on the composition of sea water, $\mathrm{p}$. 26-77.In M. N. Hill [ed.], The Sea. Interscience.

[34] Chiaudani G. \& Vighi M.(1978). Metodologia standard di saggio algale per lo studio della contaminazione delle acque marine, Quad. Instituto di Ricerca Sulle Acque (IRSA), 39, 120 pp.

[35] Faragallah, H.M. (1995). Sediment-water interface chemistry in the Eastern Harbour, Alexandria, Egypt. MSc. Thesis, Faculty of Science, Alexandria University, 277p.

[36] Zaghloul F.A. (1996). Further studies on the assessment of eutrophication in Alexandria harbours Egypt, Bulletin of Faculty of Science (Alexandria University), 36(1): 281-294.

[37] Franco, P. (1983). Fattori influence Sulla productivita dell Adriatica Settentrionale. Proc. Int. Cont. Problems of Adriatic Sea, Trieste, pp. 155 - 174. 